\title{
Human Resource Management for Increasing Employees' Satisfaction and Enhancing Competitive Strengths
}

\author{
Submitted 10/04/20, $1^{\text {st }}$ revision 19/05/20, $2^{\text {nd }}$ revision $25 / 06 / 20$, accepted 15/08/20
}

\author{
Sumarsid, ${ }^{1 *}$ Tri Erie Wardhani, ${ }^{2}$ Aripin ${ }^{3}$
}

\begin{abstract}
:
Purpose: This study aims to discuss impacts of human resource management practice in efforts to achieve competitive strengths by means of employees' mediation within the context of five-stars hotels in Jakarta.

Design/Methodology/Approach: The study used a quantitative approach by examining the hypothesis and applying SEM structural equation modelings. The data is collected from 191 employees by way of questionnaires distributed to respondents from Tourism Sector, particularly, those five-stars hotels located in Jakarta.

Finding: This study revealed a significant influence on competitive strength brought about by human resources practices. Yet, human resources management practice unlikely led to significant influence on employees' job satisfaction. Whereas, satisfaction on work performance produced significant positive impacts on competitive strength. Furthermore, it was clear that human resource management practice unlikely mediated impacts of human resources practice on competitive strengths of the employees of five-stars hotels in Jakarta.

Practical Implications: The results are interesting from the practical aspect to be applied for the improvement of the enterprise job satisfaction in the tourism sector.

Originality/value: This paper examines job satisfaction when human resource practices increase competitive advantage.
\end{abstract}

Keywords: Competitive strengths, employees satisfaction, practice of human resources.

JEL Code: M10, M11, M12.

Paper Type: Research study.

\footnotetext{
${ }^{1}$ Lecture of School of Management Labora Jakarta. Email: marsiddpk05@gmail.com.

${ }^{2}$ Lecture of Patria Indonesia's tourism academy. Email: riewardhani762@gmail.com

${ }^{3}$ Lecture of School of Management Labora Jakarta. Email: 4rlfin007@gmail.com
} 


\section{Introduction}

Hotel industry, as an element within groups of hospitality industry, is closely related to tourism sectors. Today, tourism industry whose links are elements related to other supporting ones such as travel and hotel industries have globally merged into the most enormous industries worldwide. While in Indonesia, the tourism sector has contributed significant foreign exchange as well as encouraged the growth of national economy. Internationally, despite being the backbone to the national economy, tourism has unlikely grown a significant competitiveness; it is comparatively low as its position is at number 74 worldwide or below these of the three ASEAN countries namely Singapore, Malaysia and Thailand.

Regarding tourism, hotels are one of the most inseparable supporting elements to ensure the growth of competitiveness. Along with their rapid growth, these days hotels are not only places to stay but they also provide numerous functions. For example, international summits wherein heads of countries meet are held at hotels. Similarly, hotels are also the venues for national assemblies, conferences, seminars, workshops, exhibitions and business promotions. The hotel industry today must review and optimize its performance so that hospitality has superior value in serving customers (Brown, Thomas, and Bosselman, 2015). Companies that want to maintain the continuity of their business need to find the right strategy in terms of technology, innovation, and human resources to face challenges by identifying the company's strengths, weaknesses, opportunities, and threats in accordance with its vision and mission (Uysal, 2013; Utami, Jasmine, and Guzman, 2020).

The world has undergone significant transformations in technology development and human resources practice (Collins, 2007; Malik and Kotabe, 2011). Additionally, all production fields of industry get more competitive; thus, companies face tight competition in their industry (Coad and Teruel, 2013). Moreover, human resources (HR) are vital resources to organizations and they help organizations to achieve their goals (Abdul-Halim, Che-Ha, Geare, and Ramayah, 2016). Previous studies which stated that human resource management practices had a significant positive effect on competitive advantage in the hospitality context (Simon, Arnold, Jamie, William, and Alan, 2015). However, there are other researchers who claim that human resource practices do not affect competitive strength (Amarakoon, Weerawardena, and Verreynne, 2018; Elrehail, 2018). However, human resource management practice within the context of hotel industry has brought up little significant effect on employees' satisfaction (Pan, 2015). There is still little research on human resource management practices that are associated with competitive advantage in the hospitality sector (Domínguez-Falcón, Martín-Santana, and De Saá-Pérez, 2016).

Numerous companies seem to have always failed to remember employees' strengths; as a result, dissatisfaction grows among employees at work. Whereas, once given proper attention the employees will be more motivated and thus able to maintain their competitive strengths (Pan, 2015; Masum and Khan, 2019). Employees' 
satisfaction is the key to achieve the organization's goals (William, Schneider, Barbera, and Young, 2012). Cao and Chen (2016) declared that employees' satisfaction is a leverage to enhance work productivity. Companies should be largely benefited when employees' satisfaction is increased (Chi and Gursoy, 2009; Matzler and Renzl, 2007).

Other studies also noted that satisfied employees would likely to produce competitive strengths (Ellinger, Ellinger, and Keller, 2003; Matzler and Renzl, 2007). Furthermore, deriving from the gaps resulted from literature reviews between human resource management practice and competitive strengths this study aims to investigate and describe how the relation between human resource management practice and competitive strengths through mediation model on satisfaction of the employees working for the five-stars hotels in DKI Jakarta is likely to be.

\subsection{Human Resource Management}

Human resource management is a process that consists of planning, organizing, leading and controlling activities related to job analysis, job evaluation, procurement, development, compensation, promotion, and termination of employment in order to achieve the stated goals (Pangabean, 2007). Human resource management is the potential that is an asset and functions as capital in business organizations, which can be realized into real potential physically and nonphysically in realizing the existence of the organization. Human resource management (HRM) is one area of general management that includes aspects of planning, organizing, actuation and controling (Milkovich and Boudreau, 1994). The main objective of human resource management is to increase contributions employee to the organization in order to achieve the productivity of the organization concerned. This can be understood because all the activities of the organization in achieving its goals, depends on the people who manage the organization concerned. Therefore, human resources must be managed in order to be effective in achieving organizational goals.

\subsection{Job Satisfaction}

Job satisfaction is an emotional attitude that expresses pleasure and likes work. This attitude is reflected in work morals, discipline and work performance. Job satisfaction comes as effectiveness and emotional reactions to various factors of work (Dowling and Pfeffer, 1975). Job satisfaction is a positive feeling towards a job that comes from evaluating its characteristics (Robbins and Judge, 2003). The notion of job satisfaction is a positive or negative attitude reflected by employees towards the work they live (Baron and Greenberg, 2003). Job satisfaction is the result of employees' views related to how the work they do in providing important value. Good management in the company will try to ensure stability in the work's atmosphere. It is common for someone to love work when it has the opportunity to explore expertise and skills. Employees are given the opportunity to learn and obtain 
some responsibility so as to make their work a challenging and interesting task. The match between the work done and the capabilities possessed will provide job satisfaction and encourage employees to further increase productivity. Employees will always demand a salary system that is fair and transparent as they wish. Fair pay is adjusted to the workload, level of expertise and work experience. Besides this educational background will affect the amount of salary received compared to other employees with the same position in other companies (Dowling and Pfeffer, 1975).

\subsection{Competitive Advantage}

Competitive advantage is the advantage over competitors obtained by offering lower value or by providing greater benefits because of higher prices (Kotler and Amstrong, 2003). Competitive advantage is everything that is done very well by a company compared to its competitors (Hunger and Wheelen, 2000). When a company can do something and another company cannot, or has something that its competitors want, it illustrates competitive advantage.

Having and maintaining competitive advantage is very important for the long-term success of an organization. Generally, a company is able to maintain competitive advantage only for a certain period due to emulation of competitors and the weakening of those advantages. Competitive advantage is the heart of a company's performance in a competitive market, but after decades of great expansion and prosperity, many companies lost sight of competitive advantage in the struggle to develop more in the pursuit of diversification. The essence of the formulation of a competitive strategy is to connect companies with their environment even though the highly relevant environment is very broad, encompassing social forces and also economic forces, a key aspect of the corporate environment is the industries in which the company competes (Porter, 2008).

\subsection{Human Resource Management Practice and Competitive Strengths}

Throughout the precarious global market many organizations tend to focus on human resource practices to encounter challenges and gain competitive strengths (Cania, 2014). Competitive strengths would possibly be accomplished by way of effective human resource management held within the company (Harter, Schmidt, and Hayes, 2002). To achieve competitive strength, the requirements are the skills and abilities of employees in performing (Sikora, Thompson, Russell, and Ferris, 2015). With reference to such issue, a study found that lowly-paid employees tend to be less satisfied compared to those well-paid employees (Frye, 2004). Moreover, Okpara (2004) declares that employees' satisfaction driven by HR management should result in competitive strengths. This is how the hypothesis structured in this study. It is described as follows:

\section{H1: Human Resource Management Practice creates significant impacts on competitive strengths.}




\subsection{Human Resources Management Practice and Employees' Satisfaction}

Job satisfaction is either a pleasurable or unpleasant emotional state therein employees perceive the job they have performed (Handoko, 2001). Management practice on human resources should be constructed to some extent to reach high employees' satisfaction (Simon et al., 2015). Additionally, human resource planning would likely affect employees' satisfaction on increase of productivity (Noe, Hollenbeck, Gerhart, and Wright, 2003). HRM practices are methods offering employees' satisfaction (Bekru, Cherie, and Anjulo, 2017). Furthermore, there are numerous human resources practices with positive contribution to employees' satisfaction in varied organizations as well as other empirical studies on similar issues which lead to the enhanced satisfaction on employees (Al-Khasawneh, 2013; Balozi and Aman, 2014; Tabiu and Nura, 2013). The hypothesis is structured as follows:

H2: Human Resource Management practices significantly affect the employees' satisfaction.

\subsection{Employees' Satisfaction and Competitive Strengths}

Michael Porter noted that several companies attained technological strengths thus, produced more quality products to meet customers' needs. Management succeeds in elevating employees' satisfaction thereby competitive strengths of the companies should be simultaneously improved (Deepa and Kuppusamy, 2011; Mahdieh, 2013). As such, the hypothesis is created as follows:

H3: Employees' Satisfaction significantly affects competitive strengths.

\subsection{Employees' Satisfaction Mediated Human Resource Practices Towards Gaining Competitive Strengths}

Job satisfaction brings about positive impacts on competitive strengths (Rothenberg, Hull, and Tang, 2017). Through its role as a mediator, job satisfaction provides positive contributions in the event of unsuccessful practice of HRM (Khan, Abbasi, Waseem, Ayaz, and Ijaz, 2016). Ashram practice enables improved job satisfaction consequently, competitive strengths are also enhanced in the end (Koedel, Li, Springer, and Tan, 2017). In regard to such matters, managers are bound to pay close attention to the related practices in order that the high extent of employees' satisfaction is achieved. Furthermore, several empirical studies demonstrated positive correlations between HRM practice and competitive strengths through job satisfaction on varied job fields (Khan et al., 2016; Nabi, Al, Ahmed, and Rahman, 2017).

H4: Employees' Satisfaction as a mediator of practices on Human Resource towards attaining competitive strengths. 


\section{Research Methods}

This study is determined by precise samples of measurement by way of 95 percent of trust value with 5 fault margins as described by social science researchers (Saunders, Lewis, and Thornhill, 2012). This study processes primary data by employing questionnaires distributed to 191 employees. Samples for this study are chosen by means of simple samplings and analyzed samples are taken from 191 questionnaires. Analysis instrument used in this study is SEM-PLS; it is chosen for its advantage for evaluating complicated models by which mediations or mediators are, in particular, available.

\section{Results and Discussion}

\subsection{Evaluation of Measurement Model}

There are three criteria applied for validating the measurement model which basically employs validity and reliability tests. Criteria like Cronbach's alpha, composite reliability and Average Variance Extracted (AVE) are utilized for data reliability and validation in the measurement model (Table 1):

Table 1. Validity and Reliability

\begin{tabular}{lcccc}
\hline \multicolumn{1}{c}{ Constructs } & $\begin{array}{c}\text { Cronbach's } \\
\text { Alpha }\end{array}$ & Rho A & $\begin{array}{c}\text { Composite } \\
\text { Reliability }\end{array}$ & $\begin{array}{c}\text { Average } \\
\text { Variance } \\
\text { Extracted (AVE) }\end{array}$ \\
Employee Empowerment & 0.771 & 0.793 & 0.841 & 0.517 \\
Employee Performance & 0.758 & 0.777 & 0.836 & 0.510 \\
Employee Relation & 0.787 & 0.801 & 0.844 & 0.538 \\
Job Analysis & 0.862 & 0.868 & 0.879 & 0.501 \\
Job Satisfaction & 0.693 & 0.711 & 0.824 & 0.516 \\
Recruitment \& Selection & 0.778 & 0.847 & 0.832 & 0.509 \\
Reward System & 0.851 & 0.872 & 0.872 & 0.527 \\
Social Support & 0.686 & 0.716 & 0.813 & 0.519 \\
Training & 0.852 & 0.879 & 0.878 & 0.521 \\
\hline
\end{tabular}

Source: Own.

\subsection{Evaluation of Structural Model}

Structural models are evaluated through four criteria namely path coefficient, determination coefficient (R2), effect size (f2), and model fit.

Path coefficient is used to examine hypotheses and make decisions at the significance level of 0,05 . Within the study, hypotheses $\mathrm{H} 1$ and $\mathrm{H} 3$ are accepted, whereas, hypotheses $\mathrm{H} 2$ and $\mathrm{H} 4$ are declined. The outcomes can be seen in Table 2 and Table 3 as follows: 
Table 2. Direct Relationship

\begin{tabular}{|c|c|c|c|c|c|}
\hline Hypothesis & Beta & $\begin{array}{l}\text { Standard } \\
\text { Deviation }\end{array}$ & $\begin{array}{c}\mathrm{T} \\
\text { Statistics }\end{array}$ & P Values & Notes \\
\hline $\begin{array}{l}\text { H1: HRM practice } \rightarrow \\
\text { Competitive Strengths }\end{array}$ & 0.338 & 0.093 & 3.581 & 0.000 & Significant \\
\hline $\begin{array}{l}\text { H2: HRM practice } \rightarrow \text { Job } \\
\text { satisfaction }\end{array}$ & -0.435 & 0.422 & 1.034 & 0.307 & Insignificant \\
\hline $\begin{array}{l}\text { H3: Job satisfaction } \rightarrow \\
\text { Competitive Strengths }\end{array}$ & 0.355 & 0.061 & 5.915 & 0.000 & Significant \\
\hline
\end{tabular}

Source: Own.

Table 3. Indiret Relationship

$\begin{array}{lccccc}\text { Hypothesis } & \text { Beta } & \begin{array}{l}\text { Standard } \\ \text { Deviation Statistics }\end{array} & \begin{array}{c}\mathrm{T} \\ \text { Values }\end{array} & \text { Notes } \\ \text { practice } \rightarrow \text { Job } & 0.146 & 0.142 & 1.023 & 0.305 & \text { Insignificant } \\ \text { titive Strengths } & & & & & \end{array}$

H4: HRM practice $\rightarrow$ Job

$\rightarrow$ Satisfaction $\rightarrow$ Competitive Strengths

Source: Own.

$\mathrm{R} 2$ reflects variance proportion percentage in dependent variables thereof which are described by independent variables. Practical rules for the range acceptable to R2 with $0,75,0,50$, and 0,25 are those defined as substantial, moderate, and weak (Henseler, Hubona, and Ray, 2016). In this current study R2 is said to be moderated in both variables. The result can be viewed at Table 4 .

f2 has been applied as a measurement for strengths of each exogenous variable in explaining endogenous variables. According to Chin (1998) the values of f2 0.02, 0.5 , and 0.35 for significant independent variable represents weak, moderate and substantial effects (Chin, 1998). The study finds effect size of HRM practice over competitive strengths, job satisfaction as moderate.

Table 4. Determination Coefficient and Effect Side

\begin{tabular}{lcccc}
\hline Constructs & \multicolumn{2}{c}{$f^{2}$} & \multicolumn{2}{c}{$R^{2}$} \\
& Job & Competitive & Job & Competitive \\
& Satisfaction & Strengths & Satisfaction & Strengths \\
HRMPractice & 0.011 & 0.129 & 0.310 & 0.405 \\
Job & & 0.124 & & \\
Satisfaction & & & & \\
\hline
\end{tabular}

Source: Own.

For the last criterion, the model fit, we use SRMR, MFI and RMS_theta as described bellow:

Standardized Root Mean Residuals (SRMR) asses the value of average differences between observed correlation and expected correlation as the absolute value of 
model criteria. SRMR value should be less than 0.10 and within the range of acceptable SRMR (Henseler et al., 2016).

Model Fit Index (NFI) represents additional fit size. MFI value should be higher than 0.90 for the acceptable fit model. Therefore, this study finds the acceptable MFI and the outcome can be viewed in Table 5 .

Root Mean Squared theta (RMS_theta) measures residual covariance matrix from external model residuals (Lohmöller, 2013). The RMS theta criterion is only workable for reflective models. However, the value of RMS_theta should be below 0.12 , the outcome can be seen in Table 5 .

Table 4. Model Fit

\begin{tabular}{|l|c|c|}
\hline \multicolumn{1}{|c|}{ Criteria } & $\begin{array}{c}\text { Saturated } \\
\text { Model }\end{array}$ & Estimated Model \\
\hline SRMR & 0.089 & 0.089 \\
\hline NFI & 0.940 & 0.940 \\
\hline RMS_theta & 0.109 & \\
\hline
\end{tabular}

Source: Own.

\section{Discussion}

The first hypothesisin this study that human resource management practice positive and significant effect on competitive advantage. The showed results that the human resource management practice significant effect on competitive advantage with a probability value of 0.000 , a margin of error of 0.05 . The second hypothesis is that the human resource management practice significant effect on job satisfaction. This study results showed that the human resource management practice insignificanteffect employee job satisfaction with a significance value of 0.307 . Thus the hypothesis is rejected. This study results not support of study (Bekru et al., 2017). which states that the human resource management practice significant effect on employee job satisfaction. The fact, this research results showed that job satisfaction significant influence on competitive advantage. This study support of the study (Deepa \& Kuppusamy, 2011) which states that job satisfactionsignificant affect on competitive advantage. It can be concluded that job satisfaction does not mediate the effect of human resource management practices on competitive advantage.

\section{Conclusion}

Research findings revealed positive significant influences of HRM practice on competitive strengths thus, hypothesis 1 is likely acceptable. The study has found insignificant influence of HRM practice on employees' satisfaction therefore, 
hypothesis 2 is declined. Moreover, this study has found positive significant influences of job satisfaction on competitive strengths hence, hypothesis 3 is acceptable. In this context, employees' satisfaction barely mediates HRM practice toward attaining competitive strengths and that makes hypothesis 4 rejected as well.

The limitation of this study is that it only uses three variables, human resource management practices are associated with competitive advantage, then employee job satisfaction as a mediating variable. While there are many factors that influence competitive advantage in the literature and not only human resource management practices. Therefore, for future research it is expected that researchers may use more variables.

\section{References:}

Abdul-Halim, H., Che-Ha, N., Geare, A., Ramayah, T. 2016. The pursuit of HR outsourcing in an emerging economy: The effects of HRM strategy on HR labour costs. Canadian Journal of Administrative Sciences, 33(2), 153-168. https://doi.org/10.1002/cjas.1370.

Al-Khasawneh, A.L. 2013. The Relation between Human Resource Management (HRM) Strategies and Job Loyalty as Practiced at the Public Relations (PR's) Units in the Government Ministries of Jordan. Journal of Management Research, 5(3), 146. https://doi.org/10.5296/jmr.v5i3.3689.

Amarakoon, U., Weerawardena, J., Verreynne, M.L. 2018. Learning capabilities, human resource management innovation and competitive advantage. International Journal of Human Resource Management, 29(10), 1736-1766. https://doi.org/10.1080/09585192.2016.1209228.

Balozi, M.A., Aman, K.D. 2014. The Effect of Training and Development and Employee Relations on Job Satisfaction: A case study of Tanzania Public Service College. Asian Journal of Research in Business Economics and Managemen, 4(4), 153-161.

Baron, A.R., Greenberg, J. 2003. Organizational Behaviour in Organization. In Understanding and managing the human side of work. Canada, Prentice Hall International.

Bekru, E.T., Cherie, A., Anjulo, A.A. 2017. Job satisfaction and determinant factors among midwives working at health facilities in Addis Ababa city, Ethiopia. PLoS ONE, 12(2), 1-16. https://doi.org/10.1371/journal.pone.0172397.

Brown, E.A., Thomas, N.J., Bosselman, R.H. 2015. Are they leaving or staying: A qualitative analysis of turnover issues for Generation Y hospitality employees with a hospitality education. International Journal of Hospitality Management, 46, 130-137. https://doi.org/10.1016/j.ijhm.2015.01.011.

Cania, L. 2014. The Impact of Strategic Human Resource Management on Organizational Performance. Economia. Seria Management, 17(2), 150-165. https://doi.org/10.4018/978-1-60566-996-0.ch011.

Cao, C.X., Chen, C. 2016. Value of employee satisfaction during the financial crisis. Managerial Finance, 42(12), 1208-1225. https://doi.org/10.1108/MF-10-2015-0288.

Chi, C.G., Gursoy, D. 2009. Employee satisfaction, customer satisfaction, and financial performance: An empirical examination. International Journal of Hospitality Management, 28(2), 245-253. https://doi.org/10.1016/j.ijhm.2008.08.003.

Chin, W.W. 1998. Commentary: Issues and Opinion on Structural Equation Modeling. MIS Quartely, 22(2), 7-16. https://doi.org/.1037//0033-2909.I26.1.78. 
Coad, A., Teruel, M. 2013. Inter-firm rivalry and firm growth: Is there any evidence of direct competition between firms? Industrial and Corporate Change, 22(2), 397-425. https://doi.org/10.1093/icc/dts018.

Collins, J. 2007. The road ahead for Islamic Finance. In Integrating Islamic Finance into the Mainstream: Regulation, standardization and Transparency. Harvard University, Islamic Finance Project.

Deepa, E., Kuppusamy, S. 2011. Impact of Performance Appraisal System on Job Satisfaction, Employee Engagement, Organizational Citizenship Behavior and Productivity. Indian Journal of Applied Research, 4(2), 4-6. https://doi.org/10.15373/2249555x/feb2014/55.

Domínguez-Falcón, C., Martín-Santana, J.D., De Saá-Pérez, P. 2016. Human resources management and performance in the hotel industry: The role of the commitment and satisfaction of managers versus supervisors. International Journal of Contemporary Hospitality Management, 28(3), 490-515. https://doi.org/10.1108/IJCHM-08-20140386.

Dowling, J., Pfeffer, J. 1975. Pacific Sociological Association Organizational Legitimacy: Social Values and Organizational Behavior. Source: The Pacific Sociological Review, 18(1), 122-136.

Ellinger, A.D., Ellinger, A.E., Keller, S.B. 2003. Supervisory coaching behavior, employee satisfaction, and warehouse employee performance: A dyadic perspective in the distribution industry. Human Resource Development Quarterly, 14(4), 435-458. https://doi.org/10.1002/hrdq.1078.

Elrehail, H. 2018. The relationship among leadership, innovation and knowledge sharing: A guidance for analysis. Data in Brief, 19, 128-133. https://doi.org/10.1016/j.dib.2018.04.138.

Handoko, T.H. 2001. Manajemen Personalia dan Sumber Daya Manusia. Yogyakarta, BPFE.

Harter, J.K., Schmidt, F.L., Hayes, T.L. 2002. Business-unit-level relationship between employee satisfaction, employee engagement, and business outcomes: A meta-analysis. Journal of Applied Psychology, 87(2), 268.

Henseler, J., Hubona, G., Ray, P.A. 2016. Using PLS path modeling in new technology research: Updated guidelines. Industrial Management and Data Systems, 116(1), 2-20. https://doi.org/10.1108/IMDS-09-2015-0382.

Hunger, T.L., Wheelen, D.J. 2000. Strategic Management and Business Policy. New York, Addison Wesley Publishing Company.

Khan, A.A., Abbasi, S.O.B.H., Waseem, R.M., Ayaz, M., Ijaz, M. 2016. Impact of Training and Development of Employees on Employee Performance through Job Satisfaction: A Study of Telecom Sector of Pakistan. Business Management and Strategy, 7(1), 29. https://doi.org/10.5296/bms.v7i1.9024.

Koedel, C., Li, J., Springer, M.G., Tan, L. 2017. The Impact of Performance Ratings on Job Satisfaction for Public School Teachers. American Educational Research Journal, 54(2), 241-278. https://doi.org/10.3102/0002831216687531.

Kotler, P., Amstrong, G. 2003. Dasar-Dasar Pemasaran. Jakarta, Indeks.

Mahdieh, D. 2013. Effects of Performance Appraisal Quality on Job Satisfaction in Multinational Companies in Malaysia. International Journal of Enterprise Computing and Business Systems, 2(1), 1-18.

Malik, O.R., Kotabe, M. 2011. Dynamic Capabilities, Government Policies, and Performance in Firms from Emerging Economies: Evidence from India and Pakistan. The Future of Global Business: A Reader, 195-238.

Masum, M.H., Khan, M.M. 2019. Impacts of Board Characteristics on Corporate 
Performance: Evidence from Bangladeshi Listed Companies. International Business and Accounting Research Journal, 3(1), 47-57.

Matzler, K., Renzl, B. 2007. Assessing asymmetric effects in the formation of employee satisfaction. Tourism Management, 28(4), 1093-1103. https://doi.org/10.1016/j.tourman.2006.07.009.

Milkovich, G., Boudreau, J. 199. Human Resource Management. R.D. Irwin, Ed., US, Inc.

Nabi, N., Al, A., Ahmed, T., Rahman, S. 2017. The Empirical Study on Human Resource Management Practices with Special Reference to Job Satisfaction and Employee Turnover at Investment Corporation of Human Resource Management Resaerch, 7(1), 54-64. https://doi.org/10.5923/j.hrmr.20170701.07.

Noe, R.A., Hollenbeck, J.R., Gerhart, B., Wright, P.M. 2003. Human resource management: Gaining a competitive advantage. New York, N.Y, McGraw-Hill Education. https://doi.org/10.16309/j.cnki.issn.1007-1776.2003.03.004.

Pan, F.C. 2015. Practical application of importance-performance analysis in determining critical job satisfaction factors of a tourist hotel. Tourism Management, 46, 84-91. https://doi.org/10.1016/j.tourman.2014.06.004.

Pangabean, M.S. 2007. Manajemen Sumber Daya Manusia. Jakarta, Ghalia Indonesia.

Porter, M. 2008. Competitive strategy. K. Publishing, Ed., Tanggerang.

Robbins, S.P., Judge, T. 2003. Essentials of organizational behavior. In Upper Saddle River, New York, Prentice Hall International.

Rothenberg, S., Hull, C.E., Tang, Z. 2017. The Impact of Human Resource Management on Corporate Social Performance Strengths and Concerns. Business and Society, 56(3), 391-418. https://doi.org/10.1177/0007650315586594.

Saunders, M., Lewis, P., Thornhill, A. 2012. Research Methods for Business Students. Pearson Education India, New Delhi, Pearson Education.

Sikora, D.M., Thompson, K.W., Russell, Z.A., Ferris, G.R. 2015. Reimagining overqualified human resources to promote organizational effectiveness and competitive advantage. Journal of Organizational Effectiveness: People and Performance, 2(1), 261-280. https://doi.org/10.1108/JOEPP-09-2015-0031.

Simon, L.A., Arnold, B.B., Jamie, A.G., William, H.M., Alan, M.S. 2015. Journal of Organizational Effectiveness: People and Performance. Journal of Organizational Effectiveness: People and Performance, 2(1), 261-280. https://doi.org/10.1108/JOEPP09-2015-0031.

Tabiu, Nura, A.A. 2013. Assessing the effects of human resource management (HRM) practices on employee job performance: A study of Usmanu Danfodiyo University Sokoto. Journal of Business Studies Quarterly, 5(2).

Utami, P., Jasmine, M., Guzman, J.De. 2020. Innovation of Technology-Based Strategies Based on Environmental Examination Organizations in Islamic Banking and Finance. Asian Journal of Multidisciplinary Studies, 3(1), 117-126.

Uysal, G. 2013. SHRM: Progress and Return. China-USA Business Review, 12(11), 1-11. https://doi.org/10.17265/1537-1514/2013.11.008.

William, H.M., Schneider, B., Barbera, K.M., Young, S.A. 2012. Personnel psychology book reviews. Personnel Psychology, 65(1), 207-210. https://doi.org/https://doi.org/10.1111/j.1744-6570.2011.01242_3.x. 